\title{
ANALISIS PENGARUH UPAYA PENGHINDARAN PAJAK TERHADAP BIAYA EKUITAS PADA PERUSAHAAN YANG TERDAFTAR DI BURSA EFEK INDONESIA
}

\author{
Budi Harsono* dan Basten Roberto Halim* \\ *Program Studi Akuntansi, Universitas Internasional Batam \\ E-mail: budi.harsono@uib.ac.id; basten.roberto.halim@gmail.com
}

\begin{abstract}
The purpose of this research analysis study is to explain and introduce what are the effects of tax avoidance measures on the financial costs of a company. This research was conducted using a sample of company data registered in the Indonesia Stock Exchange in the period 2013 to 2017. The sample used was 145 companies after being excluded companies that have the effect of avoiding negative taxes and financial statements that are incomplete or do not meet the criteria.

The results show no significant relationship between tax avoidance with the cost of equity. Research also includes moderation variables to strengthen the relationship of tax avoidance to the cost of equity. The variable of marginal moderation of incentives, outside party supervision and information quality are proven to have an effect of increasing the effect of tax avoidance on the cost of corporate equity. This shows that there are many factors that affect the cost of equity in addition to tax avoidance. The measurement of equity costs used by CAPM is one of the equity cost measurement models that can be applied in Indonesia. So the results of these studies produce unfavorable regression $r$ esults on tax avoidance efforts as measured by ETR. The results of this study only focus on Indonesia, which can only provide information benefits for Indonesian companies.
\end{abstract}

Keywords: Cost of Equity, Tax Avoidance, Marginal Incentives, Outside Monitoring, Information Quality

\section{PENDAHULUAN}

Modal merupakan salah satu hal dasar perusahaan dalam menjalankan usahanya. Dalam akuntansi sumber pendanaan awal perusahaan dapat diperoleh dari utang dan modal. Dalam pemilihan kedua alternatif pendanaan tersebut dapat menimbulkan biaya baik biaya administrasi atau biaya penurunan nilai. Biaya ekuitas terjadi atas pemilihan alternatif sumber pendanaan berupa modal atau saham (Harjito \& Martono, 2003).

Biaya ekuitas adalah biaya yang timbul sebagai akibat dari pendanaan modal berupa saham atau kepemilikan entitas. Dividen merupakan salah satu biaya yang dibayarkan kepada pemegang sahamnya atas dana yang diinvestasikan. Pada perusahaan yang melakukan penawaran saham ke publik memiliki resiko biaya ekuitas atas pergerakan harga pasar sahamnya (Hanafi, 2012).
Pada argument sebelumnya mengenai penghindaran pajak dapat mengurangi biaya ekuitas melalui bertambahnya arus kas yang diharapkan dari hasil penghematan pajak. Pengaruh ini akan semakin kuat bergantung pada margin keuntungan dari penghindaran pajak dan margin keuntungan yang dihematkan dari penghematan pajak. Kas dari hasil aktivitas penghindaran pajak dapat digunakan untuk mendanai proyek tersebut (Goh et al., 2016).

Bursa Efek Indonesia (BEI) merupakan salah satu bagian penting dari pertumbuhaan ekonomi Indonesia. BEI adalah salah satu pasar modal yang menyediakan alternatif pendanaan bagi perusahaan Indonesia. Salah satu alternatif pendanaan yang dapat dilakukan perusahaan adalah penerbitan dan penjualan saham di bursa efek atau pasar modal. Saham yang 
dijual dalam bursa efek akan dibeli oleh investor sesuai pertimbangan resiko dan persentase keuntungan yang diharapakan.

Berdasarkan data Bursa Efek Indonesia (2019) menunjukkan adanya peningkatan perusahaan yang mendaftaran sahamnya di BEI. Pada tahun 2016 terdapat 14 perusahaan yang melakukan initial public offering (IPO) atau dalam bahasa Indonesia penawaran saham perdana. Pada tahun 2017 terdapat 36 perusahaan yang menawarkan saham perdana kepada masyarakat. Pada tahun 2018 terdapat 55 perusahaan yang menawarkan saham perdana kepada masyarakat.

Pengambil keputusan atau manajemen dalam suatu entitas memerlukan perkiraan harga pasar, resiko dan waktu. Manajemen akan merencanakan suatu tindakan dengan mempertimbangkan dampak pada harga pasar perusahaan dengan keuntungan yang diharapkan. Biaya yang timbul dari kegiatan penananaman modal tersebut akan berdampak pada harga pasar saham perusahaan (Treynor, 2015).

Dalam mencapai nilai kinerja perusahaan maksimal mengharuskan manajemen menekan biaya-biaya sekecil mungkin. Proses penganggaran sumber modal diperlukan estimasi biaya modal yang akan terjadi. Manajemen mengambil keputusan kegiatan lainnya seperti sewa guna usaha akan memerlukan estimasi biaya (O'byrne \& S Young, 2000).

Dalam penelitian Easton (2004) menggunakan contoh skala besar pada perusahaan dari tahun 1993-2010 di Amerika Serikat, dapat ditemukan bahwa perbedaan antara tingginya perilaku penghindaran pajak dalam jangka pendek berhubungan dengan menurunnya biaya ekuitas. Pengukuran secara ex ante pada biaya ekuitas dapat hitung berdasarkan harga saham kini dan analisa peramalan keuntungan pada masa yang akan datang. Dalam argumen ini, biaya ekuitas dapat digunakan oleh investor menilai tingkat resiko pajak yang akan terjadi.

\section{KERANGKA TEORITIS DAN PERUMUSAN HIPOTESIS}

\subsection{Biaya Ekuitas}

Dalam penelitian Sharpe (1964), menilai bahwa biaya ekuitas dapat digunakan untuk memberikan investor gambaran pengembalian yang diharapkan. Investor akan menerima return yang lebih tinggi dari nilai expected rate of return dari saham yang dipegangnya dengan menimbulkan risiko yang lebih tinggi. Biaya ekuitas dapat memberikan investor gambaran risiko dari tingkat pengembalian tertentu. Hubungan tersebut dapat digambarkan dengan hubungan biaya atas risiko dan biaya atas waktu.

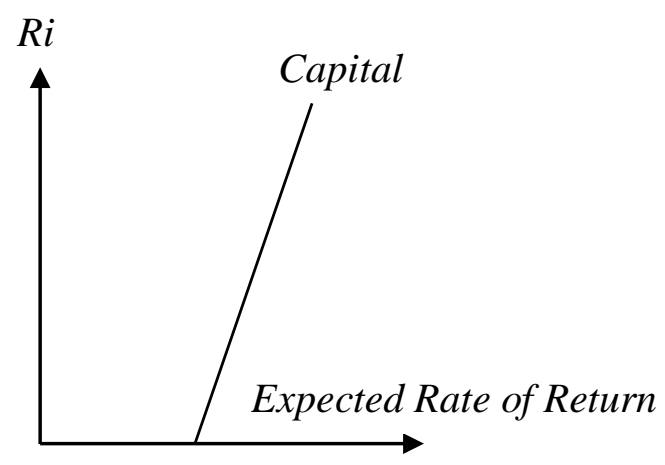

Dalam penelitian Young et al., (2000) berpendapat bahwa biaya modal atau ekuitas dapat dirumuskan atau dihitung dengan menggunakan modal yang tertanam dalam perusahaan dan dikalikan rata-rata tertimbang dari biaya modal. Dalam kasus tersebut dapat diamati bahwa biaya modal adalah suatu biaya yang terjadi ketika memilih alternatif pembiayaan modal berupa saham. Biaya ekuitas dalam sebuah instansi menjadi sebuah permasalahan atau faktor untuk pertimbangan investor melakukan pengambilan keputusan.

Proses operasi suatu perusahaan tidak akan terhindar dari biaya ekuitas. Biaya ekuitas merupakan biaya ditanggung oleh badan usaha dalam rangka untuk memilih alternatif sumber dana baik berasal dari obligasi, utang, saham preferen, atau laba ditahan untuk menjalankan atau mengoperasikan suatu perseroan. Dalam hal ini dapat dijelaskan biaya ekuitas merupakan 
biaya kesempatan bagi pemegang saham (Dr. D. Harjito dan Martono, 2003).

Biaya ekuitas dari laba ditahan terjadi karena dividen yang akan dibayarka kepada investor. Pembayaran dividen yang terjadi akan mengurangi saldo laba ditahan suatu perusahaan sesuai dengan nominal yang akan dibayarkan. Kegiatan ini secara tidak langsung meningkatnya saldo laba ditahan meningkatkan biaya dividen yang akan terjadi. Dalam kasus ini biaya ekuitas yang terjadi sama dengan jumlah dividen yang akan diberikan ke pemegang saham. Jika perusahaan memilih untuk menerbitkan saham umum yang baru maka biaya ekuitas adalah biaya harga saham dibawah harga pasar atau undervalue (Gitman, 2015).

Model CAPM merupakan hasil dari pengembangan dari penelitian Treynor (2015) yang berjudul "Market Value, Time and Risk". Dalam penelitian tersebut diteliti cara untuk investor dalam menentukan risiko investasi yang akan terjadi. Risiko tersebut terdiri dari biaya yang akan terjadi jika perusahaan memilih sumber dana berupa saham.

Biaya ekuitas adalah biaya yang terjadi karena adanya kebutuhan penanaman modal dengan menerbitkan saham. Biaya ekuitas timbul dari adanya laba ditahan pada suatu periode pembukuan perusahaan. Biaya ekuitas akan menjadi biaya saham baru dalam kondisi perusahaan telah kehabisan saldo laba ditahan (Cook, Moser, \& Omer, 2015).

Dalam penelitian Treynor (2015), biaya ekuitas dapat digunakan sebagai salah satu cara manejemen untuk menentukan pengambilan proyek dengan risiko rendah. Dengan adanya pengukuran biaya ekuitas manajemen dapat menghindari kegiatan operasi yang dapat menurunkan nilai pasar perusahaan. Biaya ekuitas tersebut juga diharapkan dapat meramal nilai pasar saham perusahaan dimasa yang akan datang dibandingkan dengan arus kas dimasa yang akan datang namun tidak pasti.

Dalam penelitian Brigham et al., (2018) perhitungan biaya ekuitas dapat dilakukan dengan pendekatan CAPM
(Capital Asset Prising Modal). Konsep perhitungan biaya ekuitas tersebut didasarkan pada harga saham yang dijual beli pada pasar dapat mencerminkan nilai masa sekarang dividen yang akan dibayarkan pada masa depan. Dividen menjadi salah satu bentuk biaya ekuitas yang paling mendasar jika memilih sumber modal berupa saham.

\subsection{Penghindaran Pajak}

Dalam penilitan Desai dan Dharmapala (2006), berpendapat bahwa aktivitas perlindungan atau pengurangan pajak dapat menutupi kesalahan manajemen dan dapat merusak nilai pemegang saham. Mereka juga menemukan bahwa tinggi insentif yang diterima oleh manajer pemegang saham berhubungan signifikan dengan rendahnya penghindaran pajak. Dalam hal ini, kemungkinan pengambilan alih kekayaan perusahaan dapat meningkatkan resiko arus kas pada perusahaan dan demikian juga pada variance dan covariance arus kas perusahaan yang meningkatkan biaya ekuitas.

Berdasarkan penelitan Lambert, Leuz, dan Verrecchia (2007) untuk mengetahui hubungan penghindaran pajak dengan biaya ekuitas dapat dikembangkan dengan model single-period multi security capital asset pricing model (CAPM) untuk mengetahui nilai biaya ekuitasnya. Model untuk menganalisis pengaruh kualitas informasi perkiraaan dalam persentase pengembalian modal atau persentase resiko, derivasi biaya ekuitas dalam menganalisa perkiraan arus kas bisa dianalisa sebagai salah satu tindakan perusahaan yang dapat mempengaruhi arus kas. Dalam menerapkan penelitian derivasi dari biaya ekuitas, dapat diargumenkan upaya penghindaran pajak dapat mempengaruhi biaya ekuitas melalui arus kas yang diharapkan pada masa yang akan datang.

Dalam penelitian Hanlon dan Slemrod (2009) berpendapat bahwa reaksi jangka pendek pasar modal dan pengembalian saham jangka panjang semua telah diungkapkan dalam kegiatan perlindungan pajak. Akan tetapi, prediksi 
atas pengembalian tersebut tidak dihubungkan atau disimpulkan ke dalam biaya ekuitas. Sehingga aktivitas penghindaran pajak tidak berpengaruh secara langsung terhadap biaya ekuitas yang terjadi perusahaan.

Sementara menurut Shevlin, Urcan, dan Vasvari (2013) berpendapat bahwa perusahaan dengan tingkat kegiatan penghindaran pajak yang lebih tinggi berdampak pada meningkatnya penyebaran pencairan surat utang publik. Penemuan ini semakin konsisten dengan para kreditur yang mengetahui resiko atas penghindaran pajak, tetapi tidak ada pembagian keuntungan dalam keberhasilan penghematan pajak. Di dalam konteks tersebut pemegang saham akan menikmati potensial meningkatnya kemungkinan arus kas dari penghematan pajak dan tambahan keuntungan tersebut dapat menutupi tambahan resiko yang terjadi dalam kegiatan penghematan pajak, dalam hal tersebut dimungkinkan adanya hubungan asosiasi berbalik antara penghindaran pajak dan biaya ekuitas.

Argumen Sikes dan Verrecchia (2014) menunjukkan bahwa ketika sebagian besar ekonomi perusahaan dipengaruhi secara signifikan oleh strategi penghindaran pajak akan menyebabkan kovariansi antara arus kas perusahaan dan arus kas pasar meningkat, dengan demikian biaya ekuitas. Dalam hal ini peneliti berasumsi bahwa meningkatnya arus kas yang diharapkan di masa depan yang berasal dari penghindaran pajak lebih besar dari peningkatan arus kas varian dan kovarian perusahaan, oleh sebab itu menimbulkan biaya ekuitas yang rendah.

Dalam penelitian Cook, Moser, dan Omer (2015) menjelaskan terdapat hubungan tingkat kegiatan penghindaran pajak dengan biaya ekuitas suatu perusahaan. Jika di dalam kegiatan penghindaran pajak disusun berdasarkan tingkat kepastian arus kas, maka investor akan memilih antara tingkat penghindaran pajak yang tinggi dengan tingkat penghematan uang yang besar tapi tidak pasti atau tingkat penghindaran pajak yang rendah dengan tingkat penghematan pajak yang rendah tetapi lebih pasti. Persepsi investor terhadap tingkat penghindaran pajak tersebut akan mempengaruhi jumlah biaya ekuitas yang akan timbul.

Penelitian dari Goh, Lee, Lim, dan Shevlin (2016) menunjukkan bahwa aktivitas penghindaran pajak dapat memberikan penghematan kas dari penghematan pajak, dimana dapat meningkat penambahan arus kas di masa yang akan datang dan dapat menurun biaya ekuitas. Namun jika aktivitas penghindaran pajak dilakukan secara agresif seperti transfer pricing dapat menimbulkan risiko arus kas di masa yang akan datang. Perusahaan akan rentan dan terbuka terhadap risiko penambahan jumlah pajak yang dibayarkan, denda dan bunga.

Berdasarkan argumen dan pendapat dari beberapa ahli diatas, Peneliti menyimpulkan adanya hubungan signifikan antara penghindaran pajak dengan biaya ekuitas. Maka berikut adalah hipotesis pertama yang akan diteliti:

$\mathrm{H}_{1}$ : Penghindaran pajak berpengaruh signifikan negatif terhadap biaya ekuitas.

\subsection{Pengaruh Margin Keuntungan Penghindaran Pajak \\ Penelitian yang dilakukan Denis \&} Sibilkov (2010) menunjukkan semakin tinggi tingkat penghematan biaya pajak yang diterima akan berpengaruh negatif terhadap biaya ekuitas konsisten dengan kurangnya alternative sumber dana yang berasal dari saham. Perusahaan dengan keuangan yang sulit akan kesulitan dalam mencari sumber modal dari luar untuk mendanai sebuah proyek yang menguntungkan. Sehingga kegiatan seperti perencanaan pajak akan dilakukan secara agresif oleh manajemen.

Kegiatan perlindungan pajak merupakan salah satu wujud tindakan lanjut yang lebih agresif dan beresiko dalam upaya penghindaran pajak yang dirancang dalam strategi kegiatan perencanaan pajak dalam satu periode. Perancangan pajak yang lebih aggresif diharapkan dapat memberikan arus kas masuk berupa biaya pajak yang diminimalkan. Argumen ini menunjukkan adanya perencanaan pajak yang lebih aggresif yang didasari tingkat pengembalian 
arus kas dimasa yang akan datang dapat berpengaruh negatif terhadap biaya ekutias entitas tersebut (Hanlon and Heitzman 2010).

Perusahaan yang memiliki tingkat laba yang tinggi akan menerima manfaat lebih besar. Jumlah kas hasil dari penghematan pajak dapat digunakan untuk mengembangkan usaha ketimbang untuk menutupi defisit operasional. Hal ini menunjukkan ada pengaruh tingkat laba perusahaan dapat memperbesar pengaruh penghindaran pajak dan kurangnya pendanaan dari saham sehingga mengakibatkan penurunan biaya ekuitas (Goh et al., 2016).

Dalam penelitian Edwards, Schwab, \& Shevlin (2016) juga menemukan bahwa semakin tingginya keterbatasan finasial akan mengarahkan perusahaan untuk menambahkan dana melalui perencanaan pajak, karena margin manfaat penghindaran pajak akan semakin besar seiring dengan semakin tingginya keterbatasan finansial sebuah perusahaan. Dalam hal ini, pengaruh margin manfaat penghindaran pajak terhadap arus kas yang diharapkan dari penghematan pajak akan semakin besar berdasarkan semakin tinggi keterbatasan finasialnya suatu perusahaan sehingga membuat pengaruh penghindaran pajak terhadap biaya ekuitas semakin meningkat dan menurunkan biaya ekuitas karena kurangnya pendanaan berupa saham.

Pada argument sebelumnya mengenai penghindaran pajak dapat mengurangi biaya ekuitas melalui bertambahnya arus kas yang diharapkan dari hasil penghematan pajak. Pengaruh ini akan semakin kuat bergantung pada margin keuntungan dari penghindaran pajak dan margin keuntungan yang dihematkan dari penghematan pajak. Kas dari hasil aktivitas penghindaran pajak dapat digunakan untuk mendanai proyek tersebut (Goh et al., 2016).

Berdasarkan pendapat para ahli mengenai marjin keutungan tersebut, maka hipotesis ketiga yang akan diteliti adalah:

$\mathrm{H}_{2}$ : Semakin kuat pengaruh marginal incentives akan meningkatkan berpengaruh signifikan negatif penghindaran pajak terhadap biaya ekuitas.

\subsection{Pengaruh Pengawasan dari Pihak Luar atau Pihak Ketiga}

Dalam penelitian Desai \& Dharmapala (2006) menemukan bahwa masalah agensi memiliki pengaruh terhadap penghindaran pajak. Permasalahan agensi yang tertanam di dalam aktivitas penghindaran pajak akan menambahkan pengalihan manajemen sumber daya perusahaan, di mana dapat menurunkan jumlah arus kas yang diharapkan. Dengan adanya pengawasan dari pihak ketiga dapat mengurangi pengalihan penghematan pajak untuk penghasilan manajer. Penelitian Desai \& Dharmapala (2006) menunjukkan pengawasan pihak luar berpengaruh negatif terhadap aktivitas penghindaran pajak sehingga secara tidak langsung berpengaruh positif terhadap biaya ekuitas.

Penelitan Desai, Dyck, \& Zingales (2007) juga menunjukan bahwa dengan tingginya tarif pajak badan berhubungan signifikan dengan pendapatan fiskal perusahaan. Pengawasan pemerintah yang ketat dapat memperkecil kesempatan manajemen melakukan aktivitas penghindaran pajak. Hasil penelitian tersebut menunjukkan hubungan negatif antar pengawasan pihak ketiga dengan aktivitas penghindaran pajak.

Tata kelola perusahaan yang baik akan menekan tingkat resiko perusahaan serendah mungkin. Dengan tingkat pengawasan yang tinggi aktivitas beresiko tinggi seperti penghindaran pajak untuk manfaat manajemen akan sangat jarang dilakukan. menunjukkan jika perusahaan memiliki tingkat pengawasan manajemen yang tinggi berpengaruh negatif terhadap tingkat penghindaran pajak. Biaya ekuitas akan meningkat seiring dengan rendahnya jumlah kas hasil penghematan biaya pajak dari kegiatan penghindaran pajak digunakan untuk manajemen seperti dividen atau insentif lainnya. (K. C. W. Chen, Chen, dan Wei, 2009). 
Pada penelitian Chen, Chen, Cheng, dan Shevlin (2010) Dalam perkembangan ekonomi, tata kelola perusahaan yang baik dapat memudahkan perusahaan dalam mendapatkan pendanaan dari luar. Aktivitas penghindaran pajak pada perusahaan keluarga meningkat seiring dengan pengawasan dari pihak ketiga yang efektif. Hal ini terjadi dengan pengawasan yang efektif mengurangi tindakan penghindaran pajak seperti rent extracting yang lebih mengutungkan manajemen dibanding perusahaan. Hasil penelitian tersebut mengakibatkan pengaruh negatif antara pengawasan pihak ketiga pada aktivitas penghindaran pajak. Manajemen akan terpaksa memilih alternatif lain yang lebih sesuai dengan peraturan perusahaan seperti dividen sehingga bepengaruh positif terhadap biaya ekuitas.

Dalam penelitian Claessens dan Yurtoglu (2013) menunjukkan adanya pengaruh negatif pengawasan baik dari tata kelola perusahaan terhadap biaya ekuitas. Tata kelola dan pengawasan yang baik dari perusahaan akan memilih alternatif sumber pendanaan dengan tingkat resiko yang terendah. Pihak manajemen dari luar akan mengutamakan keberlansungan perusahaan dengan meminimalkan tindakan yang beresiko.

Kepemilikan institusional adalah jumlah saham yang dikuasai oleh sebuat institute atau lembaga keuangan non-bank dari jumlah saham yang di terbitkan dipasar modal. Dengan adanya kepemilikan institusional diyakin dapat meningkat pengawasan dan kinerja sebuah perusahaan. Pengawasan dan pengamatan diharapakan dapat lebih optimal sehingga anggota internal perusahaan dapat meningkat kualias perusahaan. Manajemen akan mengurangi perencanaan yang beresiko dengan kurangnya jumlah pihak pengawasan. Dalam hal ini, dengan adanya menurunnya tingkat pengawasan akan meningkatkan pengaruh penghindaran pajak terhadap biaya ekuitas (Zeynali \& Dadashzadeh, 2013).

Dalam praktik Armstrong, Blouin, Jagolinzer, \& Larcker (2015) kegiatan operasional perusahaan, penghindaran pajak merupakan salah satu sumber pendanaan yang berisiko. Dalam beberapa kondisi manajemen akan mengambil alternatif sumber pendanaan dari aktivitas penghindaran pajak dengan beberapa tingkat risiko sesuai dengan kebutuhan dana yang dibutuhkan. Pengawasan dari pihak ketiga yang ketat akan membantu manajemen dalam mengambil tindakan penghindaran pajak dengan risiko serendah mungkin. Dalam hal ini menunjukkan pengawasan ketat pihak ketiga akan mengurangi risiko yang timbul dari aktivitas penghindaran pajak dan akan meningkatkan pengaruh negatif penghindaran pajak terhadap biaya ekuitas.

Berdasarkan pendapat dan argument diatas, maka berikut adalah hipotesis kedua yang akan diteliti:

$\mathrm{H}_{3}$ : Semakin kuat pengaruh outside monitoring akan meningkatkan berpengaruh signifikan positif penghindaran pajak terhadap biaya ekuitas.

\subsection{Pengaruh Kualitas Laporan Keuangan}

Penelitian Titman dan Trueman (1986) menilai bahwa kualitas sebuah laporan keuangan sangat penting terhadap segala kegiatan ekonomi perusahaan tersebut. Seorang auditor akan dapat melakukan kegiatan pengecekan laporan keuangan lebih akurat dan relevan. Laporan keuangan yang dihasilkan setelah pengecekan akan dapat memberikan gambaran kondisi perusahaan yang lebih jelas sehingga dapat digunkan oleh manajemen dalam pengendalian resiko perencaan seperti tax planning. Argumen tersebut secara tidak langsung menyimpulkan kualitas laporan keuangan dapat memperkuat hubungan penghindaran pajak terhadap biaya ekuitas.

Lee, Strong, Kahn, dan Wang (2002) memiliki argumen yang berbeda dengan berpendapat bahwa kualitas informasi yang tinggi belum tentu dapat mengurangi resiko. Kegiatan perencanaan seperti tax planning memiliki banyak faktor yang mempengaruhi tidak hanya faktor laporan keuangan. Hal tersebut dapat dipengaruhi secara langsung 
oleh iklim ekonomi dan kebijakan pemerintah yang berlaku pada masa tersebut. Dalam penelitian tersebut diungkapkan bahwa tidak signifikan pengaruh kualitas laporan keuangan terhadap kegiatan perencanaan pajak seterusnya pengaruh terhadap biaya ekuitas.

Dalam penelitian Lambert et al., (2007) mengungkapkan bahwa dengan kualitas informasi yang berkualitas akan meningkat tingkat keakuratan investor dalam meramal tingkat pengembalian uang dimasa yang akan datang. Namun tingkat ketidakpastian dalam kegiatan perencanaan pajak tidak dapat diramal secara langsung dengan adanya informasi keuangan yang handal melainkan perlu dukungan beberapa dasar pendukung lainnya seperti peraturan yang berlaku. Hubungan yang lemah antar kualitas laporan keuangan dengan kegiatan penghindaran pajak akan mengurangi pengaruhnya terhadap biaya ekuitas.

Manajemen lebih berani mengambil sebuah keputusan ekonomi dengan adanya sebuah dasar yang akurat. Tingkat kualitas laporan keuangan dapat mempengaruhi jumlah informasi yang diberikan dan kejelasan data yang disajikan. Laporan keuangan yang semakin berkualitas membuat manajemen semakin yakin dengan tindakan yang akan diambil untuk perusahaannya. Secara langsung manajemen dapat mengendalikan perusahaan dengan tingkat perencanaan yang lebih baik dan menimbulkan arus kas masuk yang lebih rendah resiko. Dengan adanya tingkat keputusan yang lebih bagus maka akan mengurangi pengaruh aktivitas penghindaran pajak dan berikutnya dan berpengaruh positif terhapa biaya ekuitas (Siregar, 2015).

Goh et al., (2016) berpendapat sama bahwa pengaruh negatif penghindaran pajak terhadap biaya ekuitas semakin kuat dengan adanya informasi laporan keuangan yang semakin akurat. Manajemen akan lebih mudah melakukan kontrol dan peramalan arus kas dengan informasi yang lebih lengkap. Tingkat kesalahan atau penyimpangan akan berkurang seiring dengan semakin lengkap dan luas informasi yang tersedia.

$\mathrm{H}_{4}$ : $\quad$ Pengaruh information quality akan memperkuat berpengaruh signifikan negatif penghindaran pajak terhadap biaya ekuitas.

\subsection{Variabel Kontrol}

Menurut Hasan, Wu, Zhang, dan Hoi (2013) menemukan bahwa dengan semakin tinggi kegiatan penghindaran pajak pada sebuah perusahaan dapat meningkatkan kemungkinan penyebaran pinjaman bank. Biaya dari sumber dana berupa saham yang semakin tinggi akan membuat manajemen mempertimbangkan sumber dana yang berasal dari hutang. Manajemen cenderung memilih alternatif sumber modal dengan biaya yang terendah.

Dalam lanjutan proses penelitian ini, Peneliti menambahkan tiga variabel kontrol untuk membantu proses uji coba. Peneliti menggunakan tiga variabel kontrol dalam model penelitian ini. Pertama, leverage merupakan ratio tingkat perbandingan utang terhapat aset pada satu periode. Kedua, BETA merupakan estimasi tingkat kembalian yang diukur melalui CAPM. Ketiga, ROA merupakan tingkat pengembalian laba terhadap jumlah aset suatu perusahaan. Dalam penelitian Goh et al. (2016) menunjukkan hubungan negatif dari ketiga variabel tersebut dengan biaya ekuitas suatu perusahaan.

\section{METODE PENELITIAN}

Penelitian yang akan dilakukan bersifat penelitian dasar berdasarkan tujuan penelitian ini. Tujuan penelitian dasar merupakan memberikan evaluasi terhadap beberapa konsep teoritis guna dalam pengembangan teori. Sifat dari penelitan ini merupakan kuantitatif dimana penelitian memecahkan masalah dengan data berupa angka sebagai dasar analisa hasil uji penelitian (Indriantoro \& Supomo, 1999).

Kombinasi metode kluasal komparatif dengan historis digunakan sebagai dasar pelaksanaan metode penelitian ilmiah ini. Metode klausal komparatif adalah pengujian dimana penelitian lebih fokus pada pengaruh 
sebab akibat antara variabel yang diteliti. Penelitian historis berarti data yang digunakan dalam penelitian merupakan data yang telah terjadi sebelumnya di masa lampau (Indriatoro \& Supomo, 1999).

Dalam penelitian ini menggunakan sampel berupa data laporan keuangan dari perusahaan yang mempublikasikannya ke Bursa Efek Indonesia (BEI). Data perusahaan yang diambil secara metode sampel. Pengambilna data secara metode sampel agar data yang digunakan dapat sesuai degan tujuan penelitian yang dilaksanakan (Indriatoro \& Supomo, 1999).

\subsection{Variabel Dependen}

Berdasarkan studi sebelumnya, untuk menghitung biaya ekuitas berdasarkan tarif diskon yang ditetapkan pasar untuk diterapkan ke arus kas di masa depan untuk mengetahui harga saham kini. Di karenakan penelitian tidak dapat secara lansung mengobservasi data arus kas di masa yang akan dating pada suatu perusahaan. Untuk mengukur biaya ekuitas menggunakan rumus berikut:

$$
C A P M=R f+\beta s(R m-R f)
$$

$C A P M=$ biaya ekuitas

$R f=$ Risk-free rate

$R m=$ pengembalian saham berdasarkan ratarata harga pasar

$\beta s=$ Saham beta , yang dihitung berdasarkan waktu tertentu

Capital Asset Pricing Model (CAPM)

digunakan dalam mengukur adanya hubungan antara pengembalian dengan resiko. Saham dapat dikategorikan sebagai salah satu bentuk investasi yang beresiko. Resiko merupakan suatu kemungkinan terjadinya fenomena penyimpangan perolehan dari tingkat pengembalian yang diharapkan (possibility). Derajat risiko (degree of risk) adalah tingkat kemungkinan terjadinya fluktuasi (amount of potential fluctuation) resiko yang akan terjadi pada tingkat pengembalian yang diharapkan (Sharpe, 1964).

\subsection{Variabel Independen}

Variabel independen dalam penelitian ilmiah ini adalah penghindaran pajak. Variabel tersebut dapat diukur melalui perbedaan buku fiskal dengan komersial atau persentase tarif pajak efektif. Melalui pertimbangan model pengukuran yang dapat memberikan penilaian penghindaran pajak, peneliti memilih pengukuran ETR yang lebih sesuai dengan kondisi laporan keuangan perusahaan di Indonesia. Berikut ini adalah rumus yang akan digunakan:

\section{ETR $=$ Tax Expense $/$ Pretax Income \\ di mana Tax Expense adalah nilai} biaya pajak kini yang dibayarkan atau yang akan dibayarkan oleh perusahaan dan Pretax Income menunjukkan penghasilan atau laba sebelum pajak perusahaan (Goh et al., 2016).

\subsection{Variabel Moderasi}

\subsubsection{Marginal Incentives}

Margin keuntungan bisa peniliti analisis dari pengukuran tingakt penjualan pada suatu perusahaan. Pengukuran yang dapat digunakan adalah pertumbuhan penjualan $(S G)$. Peneliti berargumen bahwa dengan pertumbuhan penjualan yang lebih tinggi maka pengaruh margin keuntungan dari penghematan pajak semakin kuat karena uang hasil dari penghematan semakin besar dapat digunakan untuk meningkatkan biaya ekuitas. Pengukuran pertumbuhan pendapatan diukur dengan menggunakan rumus berikut (Goh et al., 2016).

$$
S G=\left(\left(\text { sales }^{\prime} / \text { asset }\right)-\left(\text { sale }^{-1} / \text { asset }^{-}\right.\right.
$$

1)) / $\left(\right.$ sales $^{-1} /$ asset $\left.^{-1}\right)$

\subsubsection{Kepemilikian institutional}

Kepemilikan institusional adalah jumlah saham yang dikuasai oleh sebuah institusi pada sebuah badan usaha atau perusahaan dengan nilai persentase. Definisi dari istilah institusi adalah sebuah lembaga yang melakukan pengelolaan dana atas nama orang lain atau yang disebut sebagai nonbank. Variabel berikut dapat diukur dengan menggunakan metode DEDHELD yang diukur dengan jumlah kepemilikan saham institusional pada sebuah perusahaan dengan 
penilaian berupa persentase (Goh et al., 2016).

Pengukuran tersebut dilakukan berdasarkan hasil penelitan Bushee, (1998) bertopik pengaruh kepemilikan institusional. Pengukuran tersebut menggunakan jumlah kepemilikan institute dibagikan dengan jumlah pemilik atau pemegang saham perusahaan tersebut dalam sebuah periode. Dengan meningkatnya indikator tersebut maka jumlah kepemilikan institutional semakin banyak.

\subsubsection{Kualitas Laporan Keuangan}

Kualitas laporan keuangan adalah tingkat kualitas, kejelasan dan banyaknya informasi yang dapat dihasilkan dalam sebuah laporan. Kualitas laporan keuangan merupakan sebagai satu faktor yang mempengaruhi kualitas perencanaan manajemen dalam mengedalikan resiko. Indikator yang digunakan adalah EASPEED (Goh et al., 2016).

Dalam pengukuran, Peneliti menggunakan indikator EASPEED sebagai dasar pengukuran kualitas laporan keuangan. Pengukuran tersebut berdasarkan penelitian yang dilakukan oleh Francis et al., (2005) dengan perhitungan lama laporan keuangan setelah dilakukan audit oleh auditor independen dengan tanggal penutupan buku tahunan dibagi dengan 365 hari. Hal ini didasari dengan waktu audit yang lebih lama maka kualitas informasi yang dicek semakin banyak sehingga dapat meningkatkan kualitas laporan keuangan.

\subsection{Variabel Kontrol}

\subsubsection{Leverage}

Variabel ini digunakan untuk meneliti besarnya asset perusahaan yang dananya bersumber dari utang. Peneliti menduga dengan ratio leverage yang lebih tinggi, memungkinkan bahwa sumber dana perusahaan tersebut berasal dari kreditur sehingga mengurangi suntikan dana berupa investasi yang dapat menimbulkan biaya ekuitas (Goh et al., 2016).

$$
\text { Leverage }=\frac{\text { Total Debt }}{\text { Net Asset }}
$$

\subsubsection{Return on Asset}

Peniliti dapat meniliti dari jumlah penghasilan bersih dibagi dengan total asset. Peniliti menduga bahwa semakin tingginya RoA dapat merendahkan biaya ekuitas (Goh et al., 2016).

$$
R O A=\frac{\text { Net Income }}{\text { Total Asset }}
$$

\subsubsection{BETA}

BETA adalah pengukuran yang digunakan untuk mengetahui tingkat resiko suatu saham perusahaan di bursa efek. Perhitungan dilakukan dengan melakukan regresi data secara time series antara saham dengan data return pasarnya. Sesuai dengan kondisi laporan keuangan Indonesia, data yang digunakan berupa tingkat pengembalian harga pasar saham gabungan dan tingkat pengembalian saham perusahaan (Sharpe, 1964)

Pengumpulan data dimulai dari data yang tertera dalam laporan keuangan. Penelitan ilmiah ini menggunakan jenis data sekunder. Pengambilan data sekunder adalah data yang diambil dari perantara yang telah mengelola data tersebut. Data dikumpulkan dan didokumentasikan dari laporan keuangan yang dipublikasikan dari periode akhir pembukuan 31 Desember 2013 sampai dengan tahun 2017. Berikut ini adalah syarat data tersebut dapat digunakan sebagai sampel:

1. Laporan keuangan telah diaudit dan telah dipublikasikan di website BEI yaitu www.idx.co.id selama 5 tahun.

2. Nilai ekuitas perusahaan tidak negative.

3. ETR tidak boleh bernilai negatif karena dapat menimbulkan distorsi data ketika dalam pengujian.

Metode penelitian yang akan digunakan untuk menyesuaikan tujuan penelitian ini. Peneliti menggunkan metode analisis data deret waktu dengan dikombinasikan dengan analisis data kerat lintang. Penggunaan kombinasi dua metode tersebut diharapkan dapat membantu peneliti dalam mencapai tujuan dari penelitian ini. 
Dalam tahap proses pengujian akan menggunakan program aplikasi Stastistical Package for The Social Sciences (SPSS) 22. SPSS digunakan dalam pengujian analisa statistic deskriptif dan penentuan outlier pada data penelitian. Eviews adalah aplikasi yang melakukan penentuan tabel uji yang digunakan melalui uji Chow dan uji Hausman. Selanjutnya tabel yang ditentukan dapat dilakukan pengukuran atau pengujian $\mathrm{F}$ dan $\mathrm{t}$ serta melihat goodness of fit model.

Analisis deskriptif yang dilakukan melalui program SPSS 22 akan memberikan informasi dalam bentuk tabel. Informasi yang terdapat dalam tabel uji deskriptif berupa nama variabel, jumlah data penelitian, nilai maksimum dan minimum, rata-rata keseluruhan data dan standar deviasi.

Metode yang digunakan adalah Zscore untuk mendeteksi batas penyimpangan data yang wajar. Metode Zscore memiliki batasan memiliki batasan wajar sebesar $\mathrm{X}>-2.5$ dan $\mathrm{X}<2.5$ dengan data penelitian sebesar minimum 81 . Zscore adalah informasi yang diperoleh dari hasil transformasi data hasil uji deskriptif pada semua variabel penelitian.

Regresi panel merupakan proses analisis dengan struktur data yang diukur dalam jenjang waktu tertentu atau dengan kata lain yang. Data panel terdiri kombinasi data-data yang dikumpul melalui metode pengumpulan data secara time series dan cross section. Proses regresi panel memiliki 3 metode yang mampu dilakukan dengan menggunakan aplikasi eviews 7 yaitu:

1. Pooled Least Square (Common Effect) adalah salatu satu model data panel yang paling sederhana dengan terdiri dari kombinasi data time series dan cross section. Model ini tidak lagi memperhatikan dimensi waktu dan individu, sehingga data panel yang digunakan diasumsikan telah sama pada periode tersebut dan asumsi error bersifat konstan. Metode ini juga dapat digunakan dalam penelitian dengan pendekatan $O L S$ (ordinary least square). Model PLS jarang digunakan jika dibandingkan dengan dua pendekatan lainnya.

2. $\quad$ Fixed Effect Model (FEM) model ini mengasumsi variabel intersepnya atau eror dapat mengakomodasi perbedaan waktu dan individu secara tetap atau fixed. Perubahan masing-masing variabel dapat diketahui dengan metode ini sehingga sifat data lebih dinamis. Teknik pendekatan ini sering juga disebut dengan least square dummy variable (LSDV).

3. Random Effect Model (REM) model ini dapat mengestimasikan variabel gangguan atau error pada data panel yang memungkinkan adanya hubungan saling mempengaruhi. Variabel satu dengan yang lain saling berhubungan secara acak. Dalam penggunaan model ini heteroskedastisitas tidak lagi digunakan. Perbedaan variabel intersep masing-masing diakomodasikan ke masing-masing data. Model ini juga disebut dengan error component model atau generalized least square.

Dalam penentuan regresi panel yang akan digunakan akan dilakukan uji teknik estimasi model yang akan dipilih. Pengujian dilakukan untuk memilih model yang sesuai dengan kondisi data yang diteliti. Uji Chow dan uji Hausman digunakan untuk menentukan tabel regresi mana yang akan digunakan. Pada tahap pengujian pertama kali digunakan uji Chow untuk penentuan apakah data yang digunakan model PLS atau model lainnya dan diteruskan ke tahap uji berikutnya uji Hausman. Pada uji Hausman akan ditentukan pemilihan model regresi panel keterakhir apakah penggunaan tabel fixed effect atau random effect. Data yang dipilih akan digunakan untuk analisa hubungan antar variabelnya.

Uji hipotesis adalah proses pengambilan keputusan atau pross pemecahan masalah terhadap sebuah topik permasalahan. Pengujian dilakukan untuk menentukan dugaan atau hipotesis sementara terbukti atau tidak dengan populasi yang 
dipilih. Dalam tahap ini terdiri dari tiga tahap pengujian, yaitu uji $\mathrm{F}, \mathrm{t}$ dan goodness of fit model. Uji hipotesis digunakan untuk mengetahui pengaruh signifikan antara variabel data yang diuji. Nilai signifikan dinilai dari koefisien regresi secara statistik dengan model yang telah ditentukan pada tahap sebelumnya. Dalam pengujian hipotesis lebih difokuskan pada penjelasan hubungan antara variabel terikat dengan variabel bebas.

Ghozali (2013) berpendapat bahwa uji $\mathrm{F}$ dilakukan untuk mengetahui hubungan variabel bebas apakah telah secara simultan mempengaruhi variabel terikat. Jika uji $\mathrm{F}$ terbukti maka model penelitian dapat digunakan untuk analisa data atau kegiatan peramalan informasi. Uji $\mathrm{F}$ juga diketahui Anova atau uji serentak.

Ujit $t$ adalah uji parsial yang digunakan untuk megetahui hubungan variabel bebas secara masing-masing terhadap variabel terikat. Dalam proses pengujian uji $t$ menggunakan koefisien dari tabel uji t sebagai nilai ukur signifikan. Pada tabel terdapat nilai koefisien masing-masing variabel bebas terhadap variabel terikat (Ghozali, 2013

Uji goodness of fit adalah kegiatan pengujian yang digunakan untuk menilai tingkat kecocokan hasi pengamatan variabel bebas terhadap variabel terikat. Penilaian dilakukan dengan melihat koefisien determinasi nilai $R$-square pada tabel hasil regresi t. Uji goodness of fit sering juga disebut dengan uji R. Penilaian uji R dilakukan dengan skala $0-1$. Dalam penilaian, jika nilai koefisien semakin mendekati 0 maka disimpulkan bahwa informasi yang diberikan oleh variabel bebas secara keseluruhan tidak mampu menjelaskan pengaruhnya yang terjadi terhadap variabel terikat. Sebaliknya jika semakin mendekat angka 1, maka disimpulkan bahwa variabel bebas dapat memberikan informasi yang dapat menjelaskan pengaruh yang terjadi di variabel terikat (Ghozali, 2013).

Determinasi R2 atau adjusted-R square adalah hasil uji $\mathrm{R}$ yang telah disesuaikan dengan error dalam proses penelitian. Penelitian ini menggunakan R2 dengan mempertimbangkan nilai $\mathrm{R} 2$ lebih fleksibel terhadap perubahan seperti penambahan variabel bebas sehingga menimbulkan peningkatan nilai koefisien R2. Penilaian terhadap R2 masih sama seperti dengan $\mathrm{R}$ dengan skal $0-1$.

\section{HASIL PENELITIAN}

\subsection{Statistik Deskriptif}

Tabel 1

Daftar Jumlah Perusahaan yang Dijadikan Sampel

\begin{tabular}{|l|c|c|}
\hline \multicolumn{1}{|c|}{ Keterangan } & \multicolumn{2}{c|}{ Jumlah } \\
\hline Perusahaan terdaftardi BEI periode 2013 - 2017 & 599 & Perusahaan \\
\hline Banyak perusahaan yang tidak melewati kriteria & -422 & Perusahaan \\
\hline Perusahaan yang memenuhi kriteria & 177 & Perusahaan \\
\hline Lama tahun penelitian & 5 & Tahun \\
\hline Jumlah data penelitian & 885 & Data \\
\hline Banyak data Outlier & -160 & Data \\
\hline Data yang layak diteliti & 725 & Data \\
\hline
\end{tabular}

Tabel 2

Hasil Uji Statistik Deskriptif

\begin{tabular}{|c|c|c|c|c|c|}
\hline & N & Minimum & Maximum & Mean & Std. Deviation \\
\hline Biaya Ekuitas & 725 &,- 18678 &, 22426 &, 0213270 &, 06623369 \\
\hline Penghindaran Pajak & 725 &, 00024 &, 54744 &, 2305205 &, 09722827 \\
\hline Kepemilikan Instituional & 725 &,- 09279 &, 14595 &, 0207956 &, 03585781 \\
\hline Kualitas Informasi & 725 &, 00000 &, 39800 &, 1360094 &, 08794899 \\
\hline Pertumbuhan Pendapatan & 725 &, 00000 &, 11774 &, 0420221 &, 02311623 \\
\hline
\end{tabular}




\begin{tabular}{|c|c|c|c|c|c|}
\hline Leverage & 725 &, 00072 &, 94756 &, 4809105 &, 21734006 \\
\hline ROA & 725 &,- 09415 &, 24033 &, 0603328 &, 04873430 \\
\hline BETA & 725 & $-2,92542$ & 4,36303 &, 7394810 & 1,20611157 \\
\hline Valid N (listwise) & 725 & & & & \\
\hline
\end{tabular}

Berdasarkan Tabel 1 yang telah disajikan di atas menunjukkan jumlah perusahaan yang terdaftar di Bursa Efek Indonesia mulai dari tahun 2013 sampai dengan tahun 2017 berjumlah 599 perusahaan. Sebanyak 422 perusahaan tidak memenuhi syarat ataupun tidak terdapat laporan tahunan perusahaan yang dapat diamati sebagai sampel. Terdapat 177 perusahaan yang dapat digunakan sebagai sampel penelitian dengan jumlah keseluruhan terdapat 885 data pengamatan. Sesuai dengan pembahasan sebelumnya mengenai uji outlier, terdapat 160 data tidak melewati tes outlier sehingga tersisa 725 data bersih yang dapat digunakan menjadi sampel untuk uji hipotesis.

Pada urutan tabel paling atas merupakan variabel dependen yaitu biaya ekuitas. Tabel 2 di atas memberikan informasi bahwa nilai rata-rata biaya ekuitas sebesar 0,0213270. Nilai rata-rata tersebut terjadi secara konsisten dengan peningkatan IHSG yang meningkat dalam kurun waktu 2013 - 2017. Berdasarkan standar deviasi yang diamati sebesar 0,6623369 menunjukkan bahwa penyebaran variabel relatif kecil atau sempit.

Biaya ekuitas yang menggunakan pengukuran CAPM dipengaruhi oleh faktor harga saham dan pasar. Nilai minimum biaya ekuitas sebesar -0,18678 menunjukkan bahwa adanya perusahaan mengalami penurunan harga sahamnya dibandingkan saat awal periode dan akhir periode sedangkan nilai maksimum mencapai 0,22426 yang menunjukkan harga saham perusahaan tersebut mengalami peningkatan. Perubahan persentase yang terjadi dalam pengukuran CAPM sangat sensitif dengan perubahan harga pasar saham yang diteliti.

Penghindaran pajak yang diukur dengan tarif efektif perusahan menunjukkan kemungkinan tindakan penghindaran pajak yang dilakukan oleh suatu perusahaan. Berdasarkan Tabel 2 dapat dilihat bahwa nilai maksimum $57 \%$ berselisih sangat jauh dengan nilai rata-rata $0,02 \%$. Hal ini menunjukkan masih ada perusahaan yang berkemungkinan melakukan upaya penghindaran pajak yang lebih agresif. Ratarata nilai sebesar $23 \%$ masih menunjukkan hal tingkat penghindaran pajak yang masih rendah dengan tingkat tarif pajak badan usaha indonesia sebesar $25 \%$.

Hasil uji menunjukkan rata-rata pertumbuhan pendapatan memberi pengaruh terhadap kegiatan penghindaran pajak perusahaan sebesar $2.07 \%$ menandakan adanya kemajuan perekonomian perusahaan Indonesia selama Tahun 2013 sampai 2017. Hasil uji juga menunjukkan adanya perusahaan yang menikmati kegiatan penghindaran pajak dari kenaikan penjualan dengan nilai maksimum $14,59 \%$ sedangkan nilai minimum $-9 \%$ menandakan adanya perusahaan kurang menikmati penghindaran pajak dengan defisit pertumbuhan pendapatan. Nilai maksimum tersebut menjadi hal yang penting diteliti penyebab peningkatan yang cukup tinggi menunjukkan kemungkinan kegiatan penghindaran pajak semakin tinggi.

Dalam kebijakan peraturan indonesia kepemilikan institusioanl dalam perusahaan tidak bersifat wajib. Hal ini dapat dilihat dari jumlah minimun sebesar 0 dari tabel mengeai kepemilikan institusional. Perusahaan tersebut tidak memperoleh pengaruh pengawasan dari pihak luar. Nilai maksimum mencapai 0,398 menunjukkan adanya perusahaan mendapat pengaruh besar dari pengawasan luar terhadap pengaruh penghindaran pajak terhadap biaya ekuitas. Kepemilikan dalam suatu perusahaan Indonesia masih dikuasai dan didominasi oleh non-institusional berdasarkan hasil pengamatan rata-rata hanya sebesar $0,27 \%$. Berdasarkan hasil uji standar deviasi sebesar 0,2368 memberikan kesimpulan bahwa penyebaran data relatif luas dan beragam. Secara keseluruhan dapat dijelaskan bahwa 
dalam garis besar perusahaan di Indonesia mendapat pengawasan dari pihak institusional sehingga segala kebijakan yang akan diterapkan oleh seorang manajer dalam sebuah instansi akan lebih efektif dengan adanya pengawasan dari pihak luar.

Perusahaan yang di uji pada Tabel 2 rata-rata sebesar $4 \%$ menunjukkan bahwa rata-rata pengaruh kualitas informasi terhadap penghindaran pajak perusahaan melalui kecepatan informasi keuangan disajikan. Nilai minimun $0,4 \%$ menunjukkan adanya perusahaan memiliki jangka waktu penyelesaian laporan keuangan yang lebih singkat dibandingkan nilai maksimum $11 \%$ menunjukkan adanya perusahaan yang membutuhkan waktu yang lebih lama. Standar deviasi sebesar menunjukaan 0,21734 menunjukkan bahwa perusahaan rata-rata memiliki waktu penyelesaian yang mirip ini sesuai dengan peraturan BEI memberikan batas waktu penyampaian laporan keuangan kepada masyarakat.

Ratio utang pada jumlah aset dalam jangka Tahun 2013 - 2017 memiliki nilai rata-rata $48,02 \%$ menandakan masih banyak perusahaan di Indonesia memilih sumber modal atau pendanaan perusahaan berasal utang dari pihak eksternal . Nilai maksimum sebesar 94\% menunjukkan ada perusahaan yang sumber modalnya sebagian besar dari hutang. Nilai minimum 2\% memberikan informasi ada perusahaan yang sumber modal tidak bergantung pada hutang melainkan sumber lainnya.

Hasil uji pada Tabel 2 menunjukkan ROA memiliki rata-rata $6,03 \%$ menunjukkan bahwa perusahaan Indonesia rata-rata mengalami peningkatan aset dan hal ini kosisten dengan hasil uji pertumbuhan

\subsection{Hasil Uji Regresi Panel}

Sebelum melakukan uji regresi panel peneliti akan memilih metode regresi yang paling sesuai dengan penelitian ilmiah ini. Tabel yang akan digunakan untuk analisa terdiri dari PLS, FEM dan $R E M$. Sesuai dengan pembahasan di bab pendapatan. Nilai maksimum dan minimum dari hasil uji adalah 0.24 menunjukkan ada perusahaan yang mendapatkan tingkat pengembalian aset yang tinggi. Nilai minimum sebesar -0.20 menunjukkan ada perusahaan yang mengalami pengurangan aset yang didasari dengan defisitnya jumlah pendapatan yang diterima dalam periode Tahun 2013 sampai 2017.

Pada tabel 2 dapat dilihat nilai maksimum 4.36303 menunjukkan angka peningkatan yang sangat besar dalam kurun waktu satu tahun, perisitiwa ini terjadi bagi perusahaan yang memiliki harga saham yang rendah. Nilai minimum --2.92542 menandakan ada perusahaan yang mengalami penurunan harga saham dalam kurun waktu satu tahun. Rata-rata 0,7394 menggambarkan bahwa secara keseluruhan perusahaan memiliki peningkatan harga saham selama periode 2013 - 2017. Standar deviasi 1,206 menunjukkan penyebaran jenis data semakin beragam.

\subsection{Hasil Uji Outlier}

Dalam melaksanakan uji outlier, peneliti memilih metode Zscore dengan menggunakan aplikasi SPSS dimana data hasil tes outlier akan digunakan sebagai dasar melakukan uji hipotesis melalui aplikasi Eviews. Hasil pengujian menunjukkan terdapat 160 data outlier dalam 885 data pengamatan yang tidak dapat digunakan untuk melakukan uji hipotesis. Setelah dikurangi dengan data outlier sampel yang tersisa sebanyak 725 sampel akan digunakan ke tahap uji berikutnya. Uji Zscore memiliki batasan untuk nilai wajar masing-masing batasannya adalah $-2,50$ sampai dengan $+2,50$.

sebelumnya bahwa dilakukan test uji Chow dan Hausman dalam menentukkan ketiga model tabel yang akan digunakan. Berikut merupakan penjelasan dan pemilihan metode yang digunakan dalam menwujudkan objektif dari karya ilmiah ini: 
Tabel 3

\begin{tabular}{|l|c|c|c|}
\hline Redundant Fixed Effects Tests & & & \\
\hline Test cross-section fixed effects & & & \\
\hline \multicolumn{1}{|c|}{ Effects Test } & Statistic & d.f. & Prob. \\
\hline Cross-section F & 0.907493 & $(144,573)$ & 0.7587 \\
\hline Cross-section Chi-square & 148.941507 & 144 & 0.3718 \\
\hline
\end{tabular}

Berdasarkan hasil pengamatan tabel hasil uji diatas, dapat dilihat bahwa nilai probabilitas chi-square yang didapati dari hasil uji bernilai 0,3718 . Nilai probabilitas di bawah 0,05 yang menunjukkan bahwa untuk tahap uji hipotesis berikutnya akan menggunakan metode pool least square sebagai metode dasar pengujian. Dengan telah ditentukan model pengujian maka tidak diperlukan lagi melakukan uji Hausman untuk menentukan teknik yang akan dipilih.

\subsection{Hasil Uji Hipotesis}

Tabel 4

Hasil Uji F

\begin{tabular}{|l|l|}
\hline F-statistic & 827.0817 \\
\hline Prob(F-statistic) & 0.000000 \\
\hline
\end{tabular}

Uji $F$ dilakukan dengan tujuan untuk mengetahui pengaruh variabel independen terhadap variabel dependen secara simultan. Berdasarkan hasil regresi Tabel 4, nilai signifikan variabel biaya ekuitas adalah 0,0000 sehingga menunjukkan hasil lebih kecil daripada 0,05 . Hasil tersebut menandakan bahwa variabel penghindaran pajak, penghindarn pajak yang dimoderasi kepemilikan institusional, pertumbuhan pendapatan dan kualitas infromasi serta leverage, ROA dan BETA secara simultan berpengaruh signifikan terhadap biaya ekuitas. Dengan demikian model regresi ini dapat digunakan untuk memprediksi variabel biaya ekuitas dalam penelitian dengan menggunakan sampel semua perusahaan.

\subsection{Hasil Uji t}

Tabel 5

\begin{tabular}{|c|c|c|c|c|}
\hline Variable & Coefficient & Prob. & Kesimpulan & Hipotesis. \\
\hline Penghindaran Pajak & -0.000406 & 0.9851 & Tidak Signifikan & Tidak Terbukti \\
\hline $\begin{array}{l}\text { Moderasi } \\
\text { Kepemilikan Institusional }\end{array}$ & -0.029313 & 0.0359 & Signifikan Negatif & Terbukti \\
\hline $\begin{array}{l}\text { Moderasi } \\
\text { Pertumbuhan Pendapatan }\end{array}$ & 0.058707 & 0.0002 & Signifikan Positif & Terbukti \\
\hline \begin{tabular}{|l|} 
Moderasi \\
Kualitas Informasi
\end{tabular} & -0.014183 & 0.4752 & Tidak Signifikan & Terbukti \\
\hline Leverage & -0.003776 & 0.7858 & Tidak Signifikan & Tidak Terbukti \\
\hline ROA & 0.035092 & 0.0366 & Signifikan Positif & Terbukti \\
\hline BETA & -0.940299 & 0.0000 & Signifikan Negatif & Terbukti \\
\hline R-squared & 0.860870 & \multicolumn{2}{|c|}{ Mean dependent var } & 0.020234 \\
\hline Adjusted R-squared & 0.847492 & \multicolumn{2}{|c|}{ S.D. dependent var } & 0.065491 \\
\hline S.E. of regression & 0.025576 & \multicolumn{2}{|c|}{ Akaike info criterion } & -4.396662 \\
\hline Sum squared resid & 0.034014 & \multicolumn{2}{|c|}{ Schwarz criterion } & -4.183513 \\
\hline Log likelihood & 133.5032 & \multicolumn{2}{|c|}{ Hannan-Quinn criter. } & -4.313636 \\
\hline Durbin-Watson stat & 1.385488 & & & \\
\hline
\end{tabular}

Berdasarkan Tabel 5 menjelaskan bahwa variabel penghindaran pajak yang diukur dengan pengukuran ETR memiliki nilai signifikan sebesar 0,9851 dan koefisien negative menunjukkan bahwa ETR tidak berpengaruh signifikan negatif terhadap variabel biaya ekuitas yang diukur dengan CAPM.

Berdasarakan tabel yang sama, variabel penghindaran pajak yang di moderasi oleh variabel margin insentif, pengawasan pihak luar dan kualitas informasi 
menunjukkan adanya peningkatan pengaruh. Penghindaran pajak dengan dimoderasi oleh margin insentif dan pengawasan pihak luar menunjukkan adanya pengaruh signifikan terhadap biaya ekuitas. Sedangkan yang dimoderasi dengan variabel kualitas informasi masih dalam kriteria tidak signifikan dengan menunjukkan peningkatan hubungan variabel penghindaran pajak dan biaya ekuitas.

Variabel kontrol yang terdiri dari leverage, ROA dan Beta pada tabel menunjukkan hubungannya dengan variabel biaya ekuitas. Leverage menunjukkan tidak adanya pengaruh signifikan terhadapa biaya ekuitas dengan koefisien yang negatif. Namun variabel ROA dan BETA berpengaruh signifikan terhadap biaya ekutias dengan nilai probabilitas

Persamaan regresi untuk model penelitian ini dibentuk pada pengujian hipotesis sebagai berikut:

Biaya Ekuitas $=\mathrm{C}-0.000406 \mathrm{ETR}-$ 0.029313ETRxSG + 0.058707ETRxIO $0.014183 \mathrm{ETRxES}-0.003776 \mathrm{LEV}+$ $0.035092 \mathrm{ROA}-0.940299 \mathrm{BETA}+e$

Keterangan:

ETR $=$ Penghindaran Pajak

ETRxSG = Penghindaran Pajak dimoderasi Margin Insentif

ETRxIO = Penghindaran Pajak dimoderasi Pengawasan Pihak Luar

ETRxES = Penghindaran Pajak dimoderasi Kualitas Informasi

$\mathrm{LEV}=$ Leverage

ROA = Return On Asset

$\mathrm{BETA}=\mathrm{BETA}$

$e=$ error

\subsection{Pembahasan hasil uji hipotesis 1:}

Berdasarkan hasil regresi menunjukkan nilai probabilitas pengaruh variabel penghindaran pajak sebesar 0,9873 terhadap variabel biaya ekuitas dengan koefisien negatif. Nilai probabilitas lebih besar dari 0,05 menunjukkan adanya hubungan tidak signifikan antara kedua variabel tersebut. Koefisien negatif memberika informasi bahwa hubungan kedua variabel tersebut adalah negatif. Hasil penelitian ini bertentangan dengan penelitian yang dilakukan oleh Desai dan Dharmapala (2006), Lambert, Leuz, dan Verrecchia (2007), Sikes dan Verrecchia (2014), Cook et al., (2015), dan Goh et al., (2016) yang menunjukkan bahwa adanya hubungan signifikan antara penghindaran pajak dan biaya ekuitas.

Hasil regresi memberikan hasil uji yang konsisten dengan argumen Desai, Dyck, dan Zingales (2007) dan Hanlon dan Slemrod (2009). Dalam Penelitan menunjukkan bahwa kurangnya pengaruh penghindaran pajak terhadap biaya ekuitas. Hasil penelitian tersebut juga tidak menunjukkan adanya kemungkinan hubungan asosisasi positif atau negatif.

\subsection{Pembahasan hasil uji hipotesis 2:}

Berdasarkan hasil uji menunjukkan variabel penghindaran pajak dimoderasi oleh marginal insentif memiliki nilai prob sebesar 0.0370 sehingga berhubungan signifikan terhadap variabel biaya ekuitas. Pengaruh bersifat negatif diperoleh dari nilai koefisien bernilai negatif. Variabel penghindaran pajak mengalami peningkatan pengaruh setelah dimoderasi maginal insentif dilihat dari adanya kenaikan nilai prob sebelumnya 0,9873 menjadi 0,0370 .

Hasil penelitian ini sejalan dengan penelitian Denis dan Sibilkov (2010), Dyreng, Hanlon, dan Maydew (2019), Edwards, Schwab, dan Shevlin (2016) dan (Goh et al., 2016) yang menunjukkan bahwa hubungan negatif penghindaran pajak terhadap biaya ekuitas akan semakin menguat dengan adanya kepemilikan institusional.

\subsection{Pembahasan hasil uji hipotesis 3:}

Berdasarkan hasil uji pada tabel 5 diatas variabel penghindaran pajak yang dimoderasi oleh variabel pengawasan pihak luar mempunyai pengaruh yang signifikan dengan nilai probabilitas 0,0002 . Koefisien positif menunjukkan adanya pengaruh positif antara penghindaran pajak yang di moderasi oleh pengawasan pihak luar. Hasil uji konsisten dengan hipotesis bahwa 
penghindaran pajak akan berpengaruh positif signifikan terhadap biaya ekuitas dengan dimoderasi oleh pengawasan pihak luar.

Hasil regresi sesuai dengan penelitian yang dilakukan sebelumnya oleh Desai dan Dharmapala (2006), Chen, Chen, dan Wei (2009) dan Zeynali dan Dadashzadeh (2013) bahwa semakin tingginya tingkat pengawasan sebuah perusahaan akan meningkatnya pengaruh positif penghindaran pajak terhadap biaya ekuitas.

\subsection{Pembahasan hasil uji hipotesis 4:}

Hasil uji variabel penghindaran pajak yang telah dimoderasi variabel kualitas informasi mengalami peningkatan pengaruh meskipun masih belum berpengaruh signifikan. Tabel 5 menunjukkan nilai prob sebesar 0,4780 dan koefisien bernilai negatif. Hasil uji nilai prob masih dibawah 0,05 dan memiliki pengaruh yang bersifat negatif antara penghindaran pajak yang dimoderasi kualitas informasi terhadap biaya ekuitas. Hasil ini konsisten dengan hipotesis yang menunjukkan adanya variabel moderasi kualitas informasi akan memperkuat pengaruh penghindaran pajak dengan biaya ekuitas.

Hasil pengujian empiris yang dilakukan konsisten dengan hasil uji dari penelitian Titman dan Trueman (1986), Siregar (2015), dan Goh et al., (2016). Peneliti tersebut menyimpulkan adanya pengaruh kualitas informasi terhadap penghindaran pajak dan dapat memperkuat pengaruhnya terhadap biaya ekuitas. Penelitan tetap terbukti meskipun hubungan variabel penghindaran pajak yang telah dimoderasi tidak signifikan namun terbutki memperkuat

Hasil uji tabel di atas mengatakan adjusted $R$-Squared dengan nilai 0,889789 atau $88,98 \%$. Berdasarkan hasil uji tersebut disimpulkan bahwa variabel penghindaran pajak baik yang dimoderasi oleh maginal insentif, pengawasan pihak luar dan kualitas informasi serta variabel kontrol lainnya seperti leverage, ROA dan BETA mampu menjelaskan $88,98 \%$ variabel dependen yaitu biaya ekuitas. Sisanya sebesar $11,02 \%$ akan diperjelaskan oleh variabel lainnya yang tidak teliti dalam penelitian ini. Secara keseluruhan variabel yang digunakan dapat diterima sebagai proses uji empiris penelitian ini.

\section{KESIMPULAN}

\subsection{Kesimpulan}

Objektif dilakukan penelitian ilmiah ini adalah menganalisis pengaruh penghindaran pajak terhadap biaya ekuitas. Dalam penelitian variabel bebas yang digunakan terdiri dari penghindaran pajak yang di moderasi variabel maginal insentif, kepemilikan institusional dan kualitas informasi dengan menggunakan sampel perusahaan yang terdaftar di Bursa Efek Indonesia selama periode 2013 sampai dengan 2017.

Berdasarkan hasil penelitian dapat ditarik kesimpulan berupa:

1. Upaya penghindaran pajak: penghindaran pajak yang diukur dengan ETR memiliki pengaruh namun tidak signifikan variabel penghindaran pajak terhadap biaya ekuitas.

2. Pemanfaatan insentif keuntungan: variabel moderasi pertumbuhan pendapatan menunjukkan adanya memperkuat pengaruh penghindaran pajak terhadap biaya ekutias dan terdapat pengaruh signifikan negatif.

3. Pengawasan pihak luar: variabel moderasi kepemilikian institusional memberikan pengaruh signifikan positif penghindaran pajak terhadap biaya ekuitas.

4. Kualitas informasi: variabel ini juga memperkuat pengaruh penghindaran pajak terhadap biaya ekuitas. Namun dihasil akhir uji masih menunjukkan hubungan negatif dan tidak signifikan.

\subsection{Keterbatasan}

Dalam setiap penelitian tentunya terdapat keterbatasan atau kelemahan yang perlu ditindaklanjuti. Keterbatasan yang dijelaskan guna untuk memberikan masukan 
ke penelitian berikutnya sehingga dapat menghasilkan sebuah karya yang baik. Berikut ini adalah keterbatasan penelitian yang terdapat dalam karya ilmiah ini:

1. Dalam kurun waktu tahun 2013 sampai dengan 2017, masih banyak terdapat perusahaan yang tidak menyajikan laporan tahunan dalam keadaan lengkap, rapi dan relevan ke Bursa Efek Indonesia sehingga data observasi yang digunakan sebagai bahan penelitan berkurang.

2. Secara pengukuran masih perlu dilakukan pengukuran model lain biaya ekuitas dan penghindaran pajak. Peneliti menggunakan $C A P M$ yang didasari atas kurang informasi laporan keuangan Indonesia sehingga sulit menemukan hubungan dengan penghindaran pajak yang diukur melalui ETR.

\subsection{Rekomendasi}

Berikut merupakan rekomendasi dari peniliti jika penelitian ini digunakan untuk melakukan penelitian berikutnya:

1. Memperluas penelitian dengan menambahkan tahun sampel penelitian.

2. Mengembangkan topik yang meneliti perbandingan biaya ekuitas di Indonesia dengan negara lain.

3. Menambahkan beberapa model pengukuran pada variabel terikat dan bebas untuk memberikan hasil hipotesis yang lebih akurat.

\section{DAFTAR PUSTAKA}

Armstrong, C. S., Core, J. E., Taylor, D. J., \& Verrecchia, R. E. (2011). When Does Information Asymmetry Affect the Cost of Capital? Journal of Accounting Research, 49(1), 1-40. https://doi.org/10.1111/j.1475679X.2010.00391.X

Armstrong, C. S., Blouin, J. L., \& Larcker, D. F. (2012). The incentives for tax planning. Journal of Accounting and Economics, 53(1-2), 391-411. https://doi.org/10.1016/j.jacceco.2011 .04 .001

Armstrong, C. S., Blouin, J. L., Jagolinzer, A. D., \& Larcker, D. F. (2015). Corporate governance, incentives, and tax avoidance. Journal of Accounting and Economics, 60(1), 117.

https://doi.org/10.1016/j.jacceco.2015 .02 .003

Bushee, B. J. (1998). The Influence of on Institutional $\mathrm{R} \quad \& \quad \mathrm{D}$ Behavior Investors Myopic Investment. 73(3), 305-333.

Chen, K. C. W., Chen, Z., \& Wei, K. C. J. (2009). Legal protection of investors, corporate governance, and the cost of equity capital. Journal of Corporate Finance, 15(3), 273-289. https://doi.org/10.1016/j.jcorpfin.200 9.01.001

Chen, S., Chen, X., Cheng, Q., \& Shevlin, T. (2010). Are family firms more tax aggressive than non-family firms? Journal of Financial Economics, 95(1), 41-61. https://doi.org/10.1016/j.jfineco.2009. 02.003

Claessens, S., \& Yurtoglu, B. B. (2013). Corporate governance in emerging markets: A survey. Emerging Markets Review, 15(February), 1-33. https://doi.org/10.1016/j.ememar.201 2.03.002

Cook, K. A., Moser, W. J., \& Omer, T. A. (2015). Tax Avoidance and Ex Ante Cost of Capital. Journal of Business Finance and Accounting, 44(7-8), 1109-1136

Denis, D. J., \& Sibilkov, V. (2010). Financial constraints, investment, and the value of cash holdings. Review of Financial Studies, 23(1), 247-269. https://doi.org/10.1093/rfs/hhp031

Desai, M. A., \& Dharmapala, D. (2005). Corporate Tax Avoidance and Firm Value. SSRN Electronic Journal, 91(August), 537-546. https://doi.org/10.2139/ssrn.689562. 
Desai, M. A., \& Dharmapala, D. (2006). Corporate tax avoidance and highpowered incentives. Journal of Financial Economics, 79(1), 145-179. https://doi.org/10.1016/j.jfineco.2005. 02.002

Desai, M. A., Dyck, A., \& Zingales, L. (2007). Theft and taxes. National Bureau of Economic Research, (1), 47.

Dhaliwal, D., Heitzman, S., \& Li, O. Z. (2005). Taxes , Leverage, and the Cost of Equity Capital.

Dr. D. Harjito, A., \& Martono, D. (2003). Manajemen Keuangan (2nd ed.). Yogyakarta.

Dyreng, S. D., Hanlon, M., \& Maydew, E. L. (2008). Long - Run Corporate Tax Avoidance. The Accounting Review, 83(1),

$61-82$ https://doi.org/10.2308/accr.2008.83. 1.61

Dyreng, S. D., Hanlon, M., \& Maydew, E. L. (2019). When does tax avoidance result in tax uncertainty? Accounting Review, 94(2), 179-203. https://doi.org/10.2308/accr-52198

Easton, P. D., Ohlson, I., Christie, A., Bouwens, J., Chen, K., Choi, T. H., Taylor, G. (2004). The implied expected rate of return on equity capital. The Accounting Review, 79(1), 73-95.

Edwards, A., Schwab, C., \& Shevlin, T. (2016). Financial constraints and cash tax savings. Accounting Review, 91(3), 859-881. https://doi.org/10.2308/accr-51282

Eugene F. Brigham, Joel F. Houston, BanyAriffin, A. N., Kee, K. Y., \& Junming, H. (2018). ESSENTIALS OF FINANCIAL MANAGEMENT (4th ed.).

Francis, J., Lafond, R., Olsson, P., \& Schipper, K. (2005). The market pricing of accruals quality $\$ .39,295-$ 327.

https://doi.org/10.1016/j.jacceco.2004 .06 .003
Ghozali, I. (2013). Aplikasi analisis multivariate dengan program SPSS (7th ed.). Semarang: Badan Penerbit Universitas Diponegoro.

Gitman, lawrence j. (2015). principles of managerial finance (14th ed.). Pearson.

Goh, B. W., Lee, J., Lim, C. Y., \& Shevlin, T. (2016). The effect of corporate tax avoidance on the cost of equity. Accounting Review, 91(6), 16471670. https://doi.org/10.2308/accr51432

Hanafi, M. (2012). Manajemen Keuangan (1st ed.). Yogyakarta: BPFE.

Hanlon, M., \& Slemrod, J. (2009). What does tax aggressiveness signal? Evidence from stock price reactions to news about tax shelter involvement. Journal of Public Economics, 93(1-2), 126141.

https://doi.org/10.1016/j.jpubeco.200 8.09.004

Hasan, I., Wu, Q., Zhang, H., \& Hoi, C. K. S. (2013). Beauty is in the Eye of the Beholder: The Effect of Corporate Tax Avoidance on the Cost of Bank Loans. Journal of Financial Economics, $113(1), \quad 67$. https://doi.org/10.1016/j.jfineco.2014. 03.004

Indriantoro, N. \& Supomo, B. (2013). Metodiologi Penelitian Bisnis untuk Akuntansi \& Manajemen. Yogyakarta: BPFE.

Lambert, R., Leuz, C., \& Verrecchia, R. E. (2007). Accounting information, disclosure, and the cost of capital. Journal of Accounting Research, 45(2), 385-420. https://doi.org/10.1111/j.1475679X.2007.00238.x

Lee, Y. W., Strong, D. M., Kahn, B. K., \& Wang, R. Y. (2002). AIMQ : a methodology for information quality assessment. 40, 133-146.

Modigliani, F., \& Miller, M. H. M. (1963). American Economic Association Corporate Income Taxes and the Cost of Capital : A Correction. American 
Economic Review, 53(3), 433-443. https://doi.org/10.1126/science.151.3 712.867-a

Sharpe, W. (1964). Capital Asset Prices: A Theory of Market Equilibrium Under Conditions of Risk. The Journal of Finance, 19(3), 425-442. https://doi.org/10.1111/j.15406261.1964.tb02865.x

Shevlin, T. J., Urcan, O., \& Vasvari, F. P. (2013). Corporate Tax Avoidance and Public Debt Costs. SSRN Electronic Journal, $1-59$. https://doi.org/10.2139/ssrn.2228601

Sikes, S. A., \& Verrecchia, R. E. (2014). Externalities of Corporate Tax Avoidance. University of Pennsylvania.

Siregar, S. V. (2015). Pengaruh Kualitas Akrual Terhadap Biaya Utang dan
Biaya Ekuitas : Studi pada Perusahaan yang Terdaftar di Bursa Efek Indonesia Tahun 2005-2011. (September 2014).

Titman, S., \& Trueman, B. (1986). Information Quality and The Valuation of New Issues. Journal of Accounting and Economics, 8, 159172.

Treynor, J. L. (2015). Market Value, Time, and Risk. Ssrn, (Mm), 1-18. https://doi.org/10.2139/ssrn.2600356

Young, S. D., \& O'byrne, S. F. (2000). EVA and value-based management (McGraw-Hill, ed.).

Zeynali, M., \& Dadashzadeh, G. (2013). The effect of corporate governance mechanisms on corporate agency costs and excess cash. 1(12), 27172732. 